\title{
Relationship of Melatonin and Salicylic Acid in Biotic/Abiotic Plant Stress Responses
}

\author{
Josefa Hernández-Ruiz and Marino B. Arnao * \\ Department of Plant Biology (Plant Physiology), Faculty of Biology, University of Murcia, Campus de Espinardo, \\ 30100-Murcia, Spain; jhruiz@um.es \\ * Correspondence: marino@um.es; Tel.: +34-968-887-001
}

Received: 22 February 2018; Accepted: 21 March 2018; Published: 22 March 2018

\begin{abstract}
Melatonin ( $N$-acetyl-5-methoxytryptamine) was discovered in plants in 1995, while salicylic acid was the name given to the active ingredient of willow in 1838. From a physiological point of view, these two molecules present in plants have never been compared, even though they have a great number of similarities, as we shall see in this work. Both molecules have biosynthesis pathways that share a common precursor and both play a relevant role in the physiology of plants, especially in aspects related to biotic and abiotic stress. They have also been described as biostimulants of photosynthetic processes and productivity enhancers in agricultural crops. We review the coincident aspects of both molecules, and propose an action model, by which the relationship between these molecules and other agents and plant hormones can be studied.
\end{abstract}

Keywords: antioxidant; nitric oxide (NO); phytomelatonin; plant hormones; plant stress; Reactive oxygen species (ROS); salicylic acid

\section{Melatonin and Salicylic Acid in Plants}

Melatonin ( $\mathrm{N}$-acetyl-5-methoxytryptamine) is a pleiotropic molecule with a wide range of cellular and physiological actions in living organisms, including animals and plants. It was discovered in animals (cow) by Lerner and colleagues in 1958 and in 1959 in humans [1,2]. Then, in 1995, two papers simultaneously demonstrated the presence of melatonin in plants, and it is now accepted that melatonin is present in all higher plants [3,4], where it is sometimes referred to as phytomelatonin $[5,6]$. Chemically, melatonin is an indoleamine derivative of the amino acid tryptophan, and its biosynthetic melatonin pathways from tryptophan have been extensively studied in both animals and plants (Figure 1). Tryptophan is converted into 5-hydrotryptophan in animals, whereas in plants tryptophan is mainly transformed into tryptamine. These last two compounds are converted into serotonin (5-hydroxytryptamine), which is finally converted into melatonin ( $N$-acetyl-5-methoxytryptamine) through the compounds $\mathrm{N}$-acetylserotonin or 5-methoxytryptamine (see Figure 1). All the enzymes involved in melatonin biosynthesis have been described and characterized in many species of animals and plants [7].

The name salicylic acid (SA) (ortho-hydroxybenzoic acid) was given to the active ingredient of willow (Salix sp.) bark by Raffaele Piria in 1838. The first commercial production of synthetic SA began in Germany in 1874. Aspirin, a trade name for acetylsalicylic acid, was introduced by the Bayer Company in 1898 and it rapidly replaced the use of SA as it produced less gastrointestinal irritation but had similar medicinal properties [8]. Salicylic acid is a phenolic compound. The shikimic acid pathway takes part in the biosynthesis of most plant phenolic compounds. The most common pathway in plants for SA synthesis is the phenylalanine pathway (Figure 1). However, SA biosynthesis may also be carried out by the isochorismic acid pathway. The hydroxylation of benzoic acid catalyzed by the enzyme benzoic acid 2-hydroxylase synthesizes SA. Benzoic acid is synthesized by trans-cinnamic 
acid (produced from phenylalanine by the action of enzyme phenylalanine ammonia lyase), either via $\beta$-oxidation of fatty acids or via a non-oxidative pathway in which trans-cinnamic acid is hydroxylated to form ortho-coumaric acid followed by oxidation of the side chain (Figure 1) [9-12].

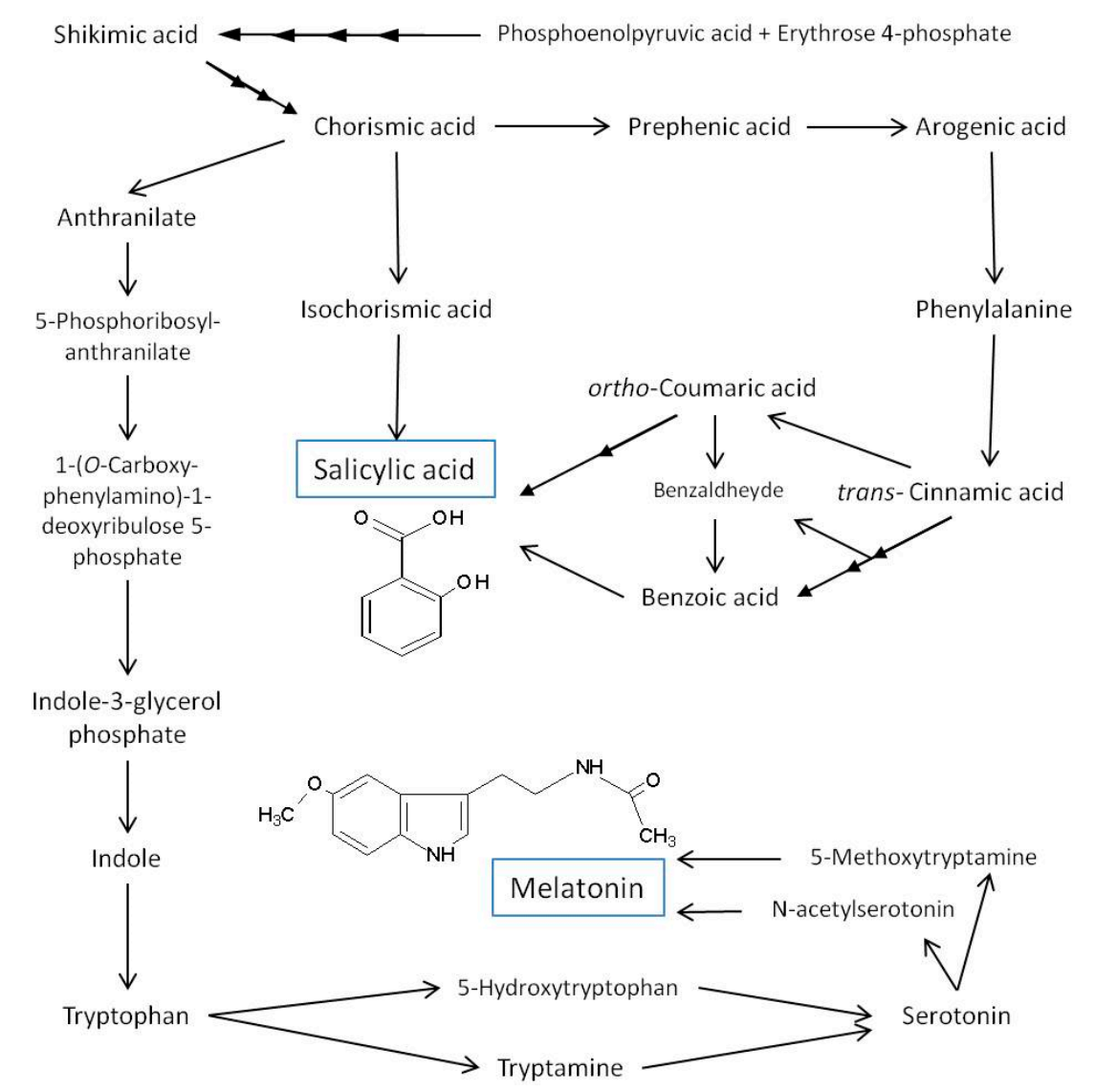

Figure 1. Biosynthetic routes of salicylic acid and melatonin in plants.

Melatonin and SA biosynthesis pathways share a final common precursor-chorismic acid-which is generated from shikimic acid (a condensation product of phosphoenolpyruvic acid from glycolysis and erythrose 4-phosphate from the pentose phosphate pathway (Figure 1). Chorismic acid is the precursor of the synthesis of three aromatic amino acids-phenylalanine, tryptophan and tyrosine. Melatonin is synthetized from tryptophan through the anthranilate/indole pathway and SA from phenylalanine, in addition to the direct isochorismic acid route (Figure 1).

With respect to catabolism, melatonin is usually hydroxylated in different positions of the indole ring, with 2-hydroxymelatonin being the major catabolite [13]. In the case of SA, several conjugates have been described, such as methyl salicylic acid, salicyloyl-L-aspartic acid, salicylic acid $2-O-\beta$-glucoside and salicyloyl-glucose ester [9].

\section{Common Effects of Melatonin and SA in Abiotic Plant Stress}

Melatonin has been considered a multiregulatory molecule in higher plants because of the wide and diverse range of cellular and physiological actions attributed to it. In 2004, the action of melatonin as a growth promoter was demonstrated in etiolated Lupinus albus [14]. Also, melatonin is able to induce root primordials from pericycle cells, generating new adventitious and lateral roots [15]. A significant role of melatonin against abiotic stress was also postulated, using a cold-induced apoptosis model in carrot cells [16]. Thus, melatonin has been attributed with the capacity to regulate cellular and plant growth; promote seed germination and rooting; optimize photosynthetic efficiency and water $/ \mathrm{CO}_{2}$ foliar exchange; regulate the internal biological clock and flowering and 
ripening/senescence processes; and finally, to act as an endogenous biostimulator against abiotic or biotic stressors $[17,18]$.

Many physiological functions have also been assigned to SA. In 1989, Carswell and colleagues reported that acetyl SA can promote colony formation in maize protoplasts, suggesting a role in the regulation of the cell cycle [19]. The first indication of a physiological effect on the part of SA was the discovery of it role in flowering induction and bud formation in tobacco cell cultures [20]. The pioneering works of Malamy et al. (1990) on the effect of SA in Tobacco Mosaic Virus [21] and of Métraux et al. (1990) on the role of SA as signaling in systemic acquired resistance (SAR) [22] clearly demonstrated the implications of SA in plant pathogen responses. Also, SA influences seed germination, seedling establishment, cell growth, respiration, stomatal closure, senescence-associated gene expression, basal thermotolerance, nodulation in legumes, and fruit yield, among others $[8,9,23,24]$. In both cases (melatonin and SA), the role in some of these processes may be indirect because they modulate the synthesis and/or signaling of other plant hormones $[25,26]$ (see below). Table 1 presents a list of the physiological effects in which both molecules (melatonin and SA) seem to play a relevant role. As can be seen, there are many coincidences between both molecules, but undoubtedly the aspects that have aroused most interest are those related to their actions in improving resistance to stress situations.

Table 1. Common physiological effects described for melatonin and SA in plants.

\begin{tabular}{cc}
\hline & Physiological Effect \\
\hline Vegetative development & $\begin{array}{c}\text { Seed germination } \\
\text { Plant growth } \\
\text { Photosynthesis } \\
\text { Mineral nutrition } \\
\text { Crop yield }\end{array}$ \\
& $\begin{array}{c}\text { Carbohydrate metabolism } \\
\text { Nitrate metabolism }\end{array}$ \\
& $\begin{array}{c}\text { Antioxidant network } \\
\text { Senescence }\end{array}$ \\
& Plant pathogen response \\
\hline Reproductive development & Flowering \\
Abiotic stresss & Seed formation \\
Sater stress: drought, flooding & \\
Salinity & Metals \\
UV, extreme light & Greater Resistance \\
Biotic stressors & \\
Fungi & \\
Bacteria & \\
\hline
\end{tabular}

Tables 2 and 3 show some representative examples in which the protective roles of melatonin and SA against different abiotic stresses have been studied. As can be seen, many aspects show close similarities between both molecules. In general, both are involved in responses to abiotic stress situations, including a marked improvement in the water status in drought situations, enhanced biosynthesis of photosynthetically active pigments as well as of the photosynthetic rate, an increase in metabolites and antioxidant enzymes to balance the redox status, osmotic adjustment to reduce of membrane injury under stress conditions, and in some cases, growth promotion and enhanced productivity and yield $[8,17,18,27-30]$. 
Table 2. Effects of melatonin in abiotic stress responses.

\begin{tabular}{|c|c|c|c|c|}
\hline Abiotic Stress & Plant Species & Melatonin Treatment $(\mu \mathrm{M})$ & Effects Observed & Reference \\
\hline Cold & Arabidopsis & $10-30$ & $\uparrow$ fresh weight, shoot height and primary roots, survival & {$[31,32]$} \\
\hline Cold & Cucumber & $50-500$ & $\uparrow$ GSH pool, $\downarrow$ ROS burst & [33] \\
\hline Cold & Rhodiola crenulata & 0.1 & $\uparrow$ cryopreservation of callus & [34] \\
\hline Cold & American elm & $0.1-0.5$ & $\uparrow$ regrowth frozen shoots & [35] \\
\hline Cold & Watermelon & 150 & $\uparrow$ photosynthesis, $\downarrow$ cold-related microRNA & [36] \\
\hline Cold & Wheat & $1 \mathrm{mM}$ & $\uparrow$ redox balance, Chls, osmorregulation, $\downarrow$ ROS burst & [37] \\
\hline Cold & Cabbage & $10-1000$ & $\uparrow$ anthocyanins, proline, redox balance, $\downarrow$ ROS burst & [38] \\
\hline Cold, salt, drought & Bermudagrass & $20-100$ & $\uparrow$ fresh weight, osmorregulation, $\downarrow$ ROS burst, cell damage & {$[39,40]$} \\
\hline Cold, salt, drought & Arabidopsis & 50 & $\uparrow$ sucrose, survival rate & [41] \\
\hline Cold, drought & Barley & $1 \mathrm{mM}$ & $\uparrow$ photosynthesis efficiency, ABA, water content, $\downarrow$ ROS burst & [42] \\
\hline Heat & Phacelia & $0.3-90$ & $\uparrow$ germination & [43] \\
\hline Heat & Arabidopsis & $5-20$ & $\uparrow$ thermotolerance & [44] \\
\hline Heat & Tomato & 10 & $\uparrow$ thermotolerance and cell protection & [45] \\
\hline Metal-Cu & Pea & 5 & $\uparrow$ plant survival & [46] \\
\hline Metal-Cu & Red cabbage & $1-100$ & $\uparrow$ fresh weight, germination, $\downarrow$ membrane peroxidation & [47] \\
\hline Metal-Cd & Tomato & $25-500$ & $\uparrow \mathrm{Cd}$ tolerance, phytochelatins, ATPase activity & [48] \\
\hline Metal-Pb & Tobacco & 0.2 & $\uparrow$ cell culture growth, $\downarrow$ mortality cells, ROS burst & [49] \\
\hline Oxidative & Arabidopsis & 5-10 & $\uparrow$ plant survival, autophagy, $\downarrow$ oxidized proteins & [50] \\
\hline Oxidative & Pisum sativum & $50-200$ & $\uparrow$ photosynthesis efficiency, pigments, water content, $\downarrow$ ROS burst & [51] \\
\hline Salinity & Malus & 0.1 & $\uparrow$ shoot height, leaf number, chlorophylls, $\downarrow$ electrolyte leakage & [52] \\
\hline Salinity & Malus & 0.1 & $\uparrow$ shoot height, $\mathrm{K}^{+}$channels, $\mathrm{K}^{+}$level, $\downarrow$ ROS burst & [53] \\
\hline Salinity & Citrus & 1 & $\uparrow$ osmorregulation, Chls, $\downarrow$ ROS burst, membrane peroxidation & [54] \\
\hline Salinity & Sunflower & 15 & $\uparrow$ root and hypocotyl growth, antioxidant potential & [55] \\
\hline Salinity & Cucumber & 1 & $\uparrow$ germination, $\mathrm{GA}_{4}, \downarrow$ ROS burst, membrane peroxidation, $\mathrm{ABA}$ & [56] \\
\hline Salinity & Vicia faba & $100-500$ & $\uparrow$ plant height, RWC, photosynthetic pigments, osmolites, phenolic & [57] \\
\hline Salinity & Tomato & $50-150$ & $\uparrow$ photosynthesis, PSII efficiency, D1 protein turnover, $\downarrow$ ROS burst & [58] \\
\hline Alkalinity & Tomato & $0.25-1$ & $\uparrow$ seedling growth, photosynthesis, ion homeostasis, $\downarrow$ ROS burst & [59] \\
\hline Salinity, drought & Soybean & $50-100$ & $\uparrow$ seedling growth, leaf size, biomass, seed yield & [60] \\
\hline Drought & Cucumber & 100 & $\uparrow$ germination, root growth & [61] \\
\hline Drought & Grape & $0.05-0.2$ & $\uparrow$ seedling growth, osmorregulation, photosynthesis, $\downarrow$ ROS burst & [62] \\
\hline Drought & Malus & 100 & $\uparrow$ water status, Chls, photosynthesis efficiency, $\downarrow$ ROS burst & [63] \\
\hline Leaf-senescence & Barley & $0.01-1$ & $\downarrow$ senescence, $\uparrow \mathrm{Chls}$ & [64] \\
\hline Leaf-senescence & Malus & $10 \mathrm{mM}$ & $\downarrow$ senescence, ROS burst, $\uparrow$ Chls, photosynthesis efficiency & {$[65,66]$} \\
\hline Leaf-senescence & Arabidopsis & $20-125$ & $\downarrow$ senescence, ROS burst, $\uparrow$ Chls, photosynthesis efficiency & [67] \\
\hline Leaf-senescence & Rice & $10-20$ & $\downarrow$ senescence, ROS burst, cell death, $\uparrow$ Chls & [68] \\
\hline Leaf-senescence & Perennial ryegrass & $20-100$ & $\downarrow$ senescence, ROS burst, $\uparrow$ Chls, photosynthesis efficiency & [69] \\
\hline
\end{tabular}

$\uparrow$, Increased content or increased action. $\downarrow$ Decreased content or decreased action. 
Table 3. Effects of SA in abiotic stress responses.

\begin{tabular}{|c|c|c|c|c|}
\hline Abiotic Stress & Plant Species & SA Treatment $(\mu \mathrm{M})$ & Effects Observed & Reference \\
\hline Cold & Hordeum vulgare & 100 & $\uparrow$ antioxidative enzymes, ice nucleation activity & [70] \\
\hline Cold & Musa acuminata & 500 & $\uparrow$ chloroplast and mitochondria ultrastructure & [71] \\
\hline Cold & Lycopersicon esculentum & 100 & $\uparrow$ resistance, antioxidative enzymes, PR proteins & [72] \\
\hline Cold & Prunus persica & $1 \mathrm{mM}$ & $\uparrow$ antioxidative enzymes, antioxidant metabolites, firmness & [73] \\
\hline Heat & Triticum aestivum & 500 & $\uparrow$ proline content, water potential, gas exchange, glutamyl kinase activity & [74] \\
\hline Heat & Arabidopsis thaliana & 10 & $\uparrow$ survival, thermotolerance, $\downarrow$ oxidative damage & [75] \\
\hline Metal-Cd & Brassica juncea & $1 \mathrm{mM}$ & $\uparrow$ mineral nutrients & [76] \\
\hline Metal-Cd & Cucumis melo & 100 & $\uparrow$ photosynthesis efficiency, water use efficiency & [77] \\
\hline Metal-Cd & Glycine max & $120 \mathrm{mM}$ & $\uparrow$ Chls, photosynthesis efficiency, antioxidative enzymes, GSH & [78] \\
\hline Metal-Cd & Ricinus communis & 500 & $\downarrow$ gas exchange, Chls & [79] \\
\hline Salinity & Glycine max & 500 & $\uparrow$ antioxidative enzymes, ascorbate & [80] \\
\hline Salinity & Vigna radiata & 500 & $\uparrow$ photosynthesis efficiency, plant dry mass, glycinebetaine & [81] \\
\hline Salinity & Torreya grandis & 500 & $\uparrow$ photosynthesis efficiency, net $\mathrm{CO}_{2}$ assimilation rates, Chls & [82] \\
\hline Drought & Zea mays & 1 & $\uparrow$ net dry weight, water potential, leaf rolling & [83] \\
\hline Drought & Simarouba glauca & 50 & $\uparrow$ polyphenols, alkaloids & [84] \\
\hline Drought & Triticum aestivum & $1 \mathrm{mM}$ & $\uparrow$ moisture content, dry mass, Rubisco, SOD, Chls & [85] \\
\hline UV-B & Poa pratensis & $150 \mathrm{mg} / \mathrm{m}^{2}$ & $\alpha$-tocopherol, SOD, CAT, anthocyanins & [86] \\
\hline
\end{tabular}

$\uparrow$, Increased content or increased action. $\downarrow$, Decreased content or decreased action. 


\section{Melatonin and SA in Biotic Stress (Plant Pathogen Response)}

Tables 4 and 5 provide a list of the papers related to the positive effect of melatonin and SA on plant pathogen responses. In the first paper, related to melatonin and fungus plant-pathogen infection, melatonin-treated apple trees using root irrigation improved the resistance of Malus prunifolia against the fungus Diplocarpon mali (Marssonina apple blotch). At 20 days, the treated trees showed a lower number of damaged leaves, higher chlorophyll content, a more efficient Photosystem II, and less defoliation than infected untreated trees. In general, melatonin helped plants with resistance to fungal infection, reducing lesions, inhibiting pathogen expansion, and generally alleviating disease damage [87]. Also, in some in vitro assays, different concentrations of melatonin showed growth inhibition activities against plant fungal pathogens such as Alternaria spp., Botrytis spp., and Fusarium spp. The same occurred in plant-pathogen attacks by Penicillium spp. in non-sterilized Lupinus albus seeds [17]. Table 4 shows five papers that used the Arabidopsis/Pseudomonas syringae as a model of plant-bacterial pathogen interaction. Melatonin induced pathogen-related genes in Arabidopsis (also in tobacco plants), which is in accordance with the possible role of this methoxyindole as a defence signalling molecule against pathogens in plants. In a recent and significant paper, Zhang et al. (2017) demonstrated that melatonin attenuates severe potato late blight caused by Phytophthora infestans. Melatonin induced plant innate immunity against fungal infection, inhibiting mycelial growth and changing expression of many genes associated with stress and virulence [88]. In sum, melatonin up-regulates pathogenesis-related, SA and ethylene-dependent genes, an effect that was suppressed in mutants defective in SA and ethylene signalling. Also, melatonin increased nitric oxide (NO) and SA-related genes, accompanied by reduced susceptibility to the pathogen, leading to an increase in both melatonin and NO. SNAT knockout mutants not only exhibited reduced levels of melatonin, but also lower levels of SA, along with a greater susceptibility to the pathogen [89]. No studies on plant viruses and melatonin have been published to date. Nevertheless, in animals, melatonin is a good therapeutic alternative for fighting bacterial, viral and parasitic infections [90]. Also, during sepsis, melatonin has been reported to block the overproduction of pro-inflammatory cytokines and increase interleukin-10 levels. With respect to viral infection, Venezuelan equine encephalomyelitis (VEE) is an important human and equine disease caused by the VEE virus. Reactive oxygen species (ROS) have been implicated in the dissemination of the responsible virus, and its deleterious effects may be diminished by melatonin treatment. The administration of melatonin significantly decreased the virus level in the blood and brain compared with the levels seen in infected control mice [90]. 
Table 4. Effects of melatonin in biotic stress responses.

\begin{tabular}{|c|c|c|c|c|}
\hline Plant Species & Biotic Stressor & $\begin{array}{c}\text { Melatonin } \\
\text { Treatment }(\mu \mathrm{M})\end{array}$ & Effects Observed & Reference \\
\hline Malus prunifolia & Diplocarpon mali & $50-500$ & $\begin{array}{l}\uparrow \text { Resistance to fungal infection } \\
\downarrow \text { Leaf lesions, cell death } \\
\downarrow \text { Pathogen expansion }\end{array}$ & [87] \\
\hline Arabidopsis and tobacco & Pseudomonas syringae DC3000 & 10 & $\begin{array}{l}\uparrow \text { Defence related genes } \\
\uparrow \text { Resistance (10-fold vs. mock) }\end{array}$ & [91] \\
\hline Arabidopsis & Pseudomonas syringae DC3000 & SE of SNAT & $\begin{array}{l}\downarrow \text { Melatonin }(50 \%), \text { SA } \\
\downarrow \text { Defence related genes } \\
\downarrow \text { Resistance to infection }\end{array}$ & [89] \\
\hline Arabidopsis & Pseudomonas syringae DC3000 & 20 & $\begin{array}{l}\uparrow \mathrm{NO} \text { and melatonin } \\
\uparrow \text { Defence related genes } \\
\uparrow \text { Resistance }\end{array}$ & [92] \\
\hline Arabidopsis and tobacco & Pseudomonas syringae DC3000 & 1 & $\uparrow$ MAP kinases cascade & [93] \\
\hline Arabidopsis & Pseudomonas syringae DC 3000 & 50 & $\begin{array}{l}\uparrow \mathrm{CBF} / \mathrm{DREB} 1 \text { (stress factors) } \\
\uparrow \mathrm{CCA1} \text { (internal clock factors) } \\
\uparrow \text { Defence related genes }\end{array}$ & {$[41,94]$} \\
\hline Lupinus albus & Penicillium spp. & $20-70$ & $\uparrow$ Resistance to fungal infection & [17] \\
\hline Rice & $\begin{array}{c}\text { Xanthomonas oryzae, XooMagnaporthe } \\
\text { oryzae, blast fungus }\end{array}$ & - & $\begin{array}{l}\text { Changes in melatonin biosynthesis } \\
\text { enzymes transcripts }\end{array}$ & [95] \\
\hline Solanum tuberosum & Phytophthora infestans & $10 \mathrm{mM}$ & $\begin{array}{l}\uparrow \text { Resistance to fungal infection } \\
\uparrow \text { fungicide effects, } \downarrow \text { virulence }\end{array}$ & [88] \\
\hline Manihot esculenta & Xanthomonas axonopodis & & $\begin{array}{l}\text { MeRAV1/2 (AP2/ERF) upregulate } 7 \text { melatonin } \\
\text { biosynthesis genes }\end{array}$ & [96] \\
\hline
\end{tabular}

With respect to SA, the exogenous application of SA at non-toxic concentrations to susceptible fruits and vegetables could enhance resistance to pathogens and help control post-harvest decay [97]. SA effectively reduced fungal decay in a concentration-dependent manner, as can be seen in the examples of Table 5. In the case of SA, some studies indicate that it inhibits viral replication [98-100].

Table 5. Effects of SA in biotic stress responses.

\begin{tabular}{cccc}
\hline Plant Species & Biotic Stressor & $\begin{array}{c}\text { SA Treatment } \\
(\mathbf{m M})\end{array}$ & \multicolumn{1}{c}{ Effects Observed } \\
\hline Fragaria ananassa & Botrytis cinerea & $1-2$ & $\downarrow$ ethylene, fungal disease, $\uparrow$ fruit quality \\
\hline Lycopersicon esculentum & Botrytis cinerea & 5 & $\begin{array}{l}\downarrow \text { ethylene, lycopene, fungal disease, } \uparrow \text { fruit } \\
\text { quality }\end{array}$ \\
\hline Mangifera indica & Collectotrichum gloeosporioides & 2 & $\uparrow$ colour, firmness, $\downarrow$ disease severity \\
\hline Malus domestica & Penicillium expansum & $0.07-0.7$ & $\uparrow$ efficacy of antagonist $C$. laurentii \\
\hline Prunus avium & Penicillium expansum & 2 & $\begin{array}{l}\uparrow \text { antioxidative enzymes, chitinase, glucanase, } \\
\text { fungal resistance }\end{array}$ \\
\hline Pyrusbretschneideri & Penicillium expansum & 2.5 & $\begin{array}{l}\uparrow \text { antioxidative enzymes, PAL, chitinase, } \\
\text { glucanase, } \downarrow \text { disease severity }\end{array}$ \\
\hline
\end{tabular}

$\uparrow$, Increased content or increased action. $\downarrow$, Decreased content or decreased action.

\section{Melatonin, SA and ROS/RNS Network}

A relevant role for $\mathrm{NO}$ in melatonin responses is proposed, mainly for auxin-like and plant immune responses. NO and other radical nitrogen species (RNS) and ROS are key signals that increase under abiotic/biotic stress $[8,106]$. Generally, RNS and ROS signals tend to act in a coordinated way. NO levels are self-regulated and also regulate the ROS network through NO-dependent, post-translational modifications [107]. NO modulates several functions through protein modifications by nitration, $S$-nitrosylation and the ligation of NO to transition metals, but also through the modification of lipids (nitro-fatty acids) and DNA (8-nitroguanine) [108-112]. Moreover, NO triggers a set of responses to alleviate stress and cellular damage, which includes transient metabolic reprogramming in both primary and secondary metabolic pathways [107].

Abiotic and biotic stress induce an increase in endogenous melatonin through the upregulation of melatonin biosynthetic genes [96,113]. Melatonin also increases NO levels through the upregulation of nitrate reductase (which usually reduces nitrate to nitrite, but can also reduce nitrite to NO using NADPH as a cofactor). Also melatonin induces the NO synthase-like pathway, in iron 
deficiency-induced NO in rice [114]. Thus, melatonin can also act as an NO and ROS scavenger, and curiously, in an NO feedback mechanism, NO induces melatonin biosynthesis [113].

Although some data point to the possibility that melatonin might act as an upstream signal, the complexity of the melatonin-NO interaction makes it difficult to elucidate whether melatonin is upstream or downstream of NO. Also, $\mathrm{H}_{2} \mathrm{O}_{2}$ (an important signal molecule in stress situations), seems to be decisive in the upregulation of melatonin biosynthesis enzymes, taking as a response an increase in melatonin levels in stressed plants. In short, mitogen-activated protein kinase (MAPK) signalling, $\mathrm{SA}, \mathrm{NO}$, and $\mathrm{H}_{2} \mathrm{O}_{2}$, as well as their cross-talk, are required for melatonin-mediated innate immunity in Arabidopsis. Also, melatonin and NO change the expression of several transcription factors and hormone signalling elements, which determines the overall anti-stress response. Also, some plant hormones such as IAA, CKs and ABA can stimulate NO production $[25,26]$.

This complex relationship between ROS, NO and melatonin is pictured in Figure 2. In the case of abiotic stress, no model including the signalling cascade for melatonin and SA has been proposed to date. Fleta-Soriano et al. (2017) studied the role of melatonin in plant response to drought stress and recovery in maize plants [115]. Furthermore, in that study, the endogenous contents of melatonin positively correlated with those of stress-related phytohormones, particularly with those of $\mathrm{SA}$, although exogenous application of melatonin did not alter the contents of any phytohormone.

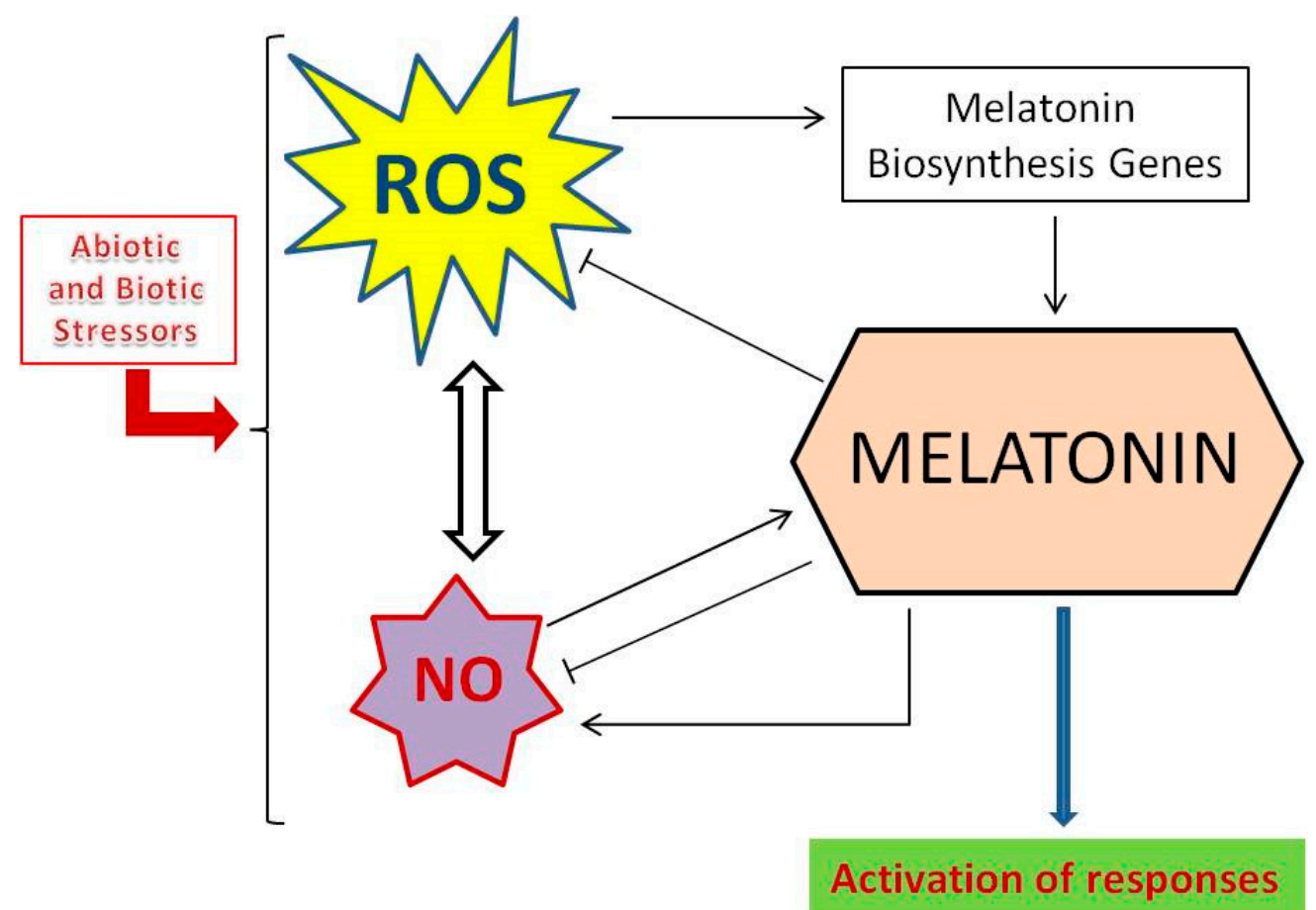

Figure 2. Effect of abiotic/biotic stressors on the antioxidant network ROS/NO/melatonin.

A model of melatonin/SA/NO/ROS action in biotic stress responses (pathogen resistance) has been proposed [9,25] (Figure 3). Pathogen attack increases NO, SA and melatonin levels through ROS. In the well-known model of Arabidopsis/Pseudomonas syringae DC3000 (avrRpt2), plant-pathogen interactions revealed that the mitogen-activated protein kinase cascade (MAPKKK3) and OXI1 (oxidative signal-inducible1) kinases are responsible for triggering melatonin-induced defence signalling pathways $[93,116]$. The key enzyme in SA biosynthesis-isochorismate synthase-1 (ICS-1) — was upregulated by melatonin, increasing SA levels and triggering a pathogen-induced response. Also, melatonin and NO were able to induce jasmonic acid (JA) biosynthesis and increase several sugar and glycerol levels, all of which activate pathogen-related gene expression. The melatonin-induction of ethylene biosynthesis, through ACC synthase (ACS6), collaborates in the 
induction of pathogenesis-related genes (PR), whereby ethylene insensitive (EIN), enhanced disease susceptibility 1 (EDS1), phytoalexin deficient 4 (PAD4) and NPR1 factors are key signalling components in the plant SA- and ethylene-mediated defence responses [17,41,91,92,96,116-119]. More recently, it has been demonstrated that MeRAV1 and MeRAV2 factors (apetala2/ethylene response factor, AP2/ERF) are essential for plant disease resistance against bacterial blight in cassava through the upstream of transcription factors of melatonin biosynthesis genes [96].

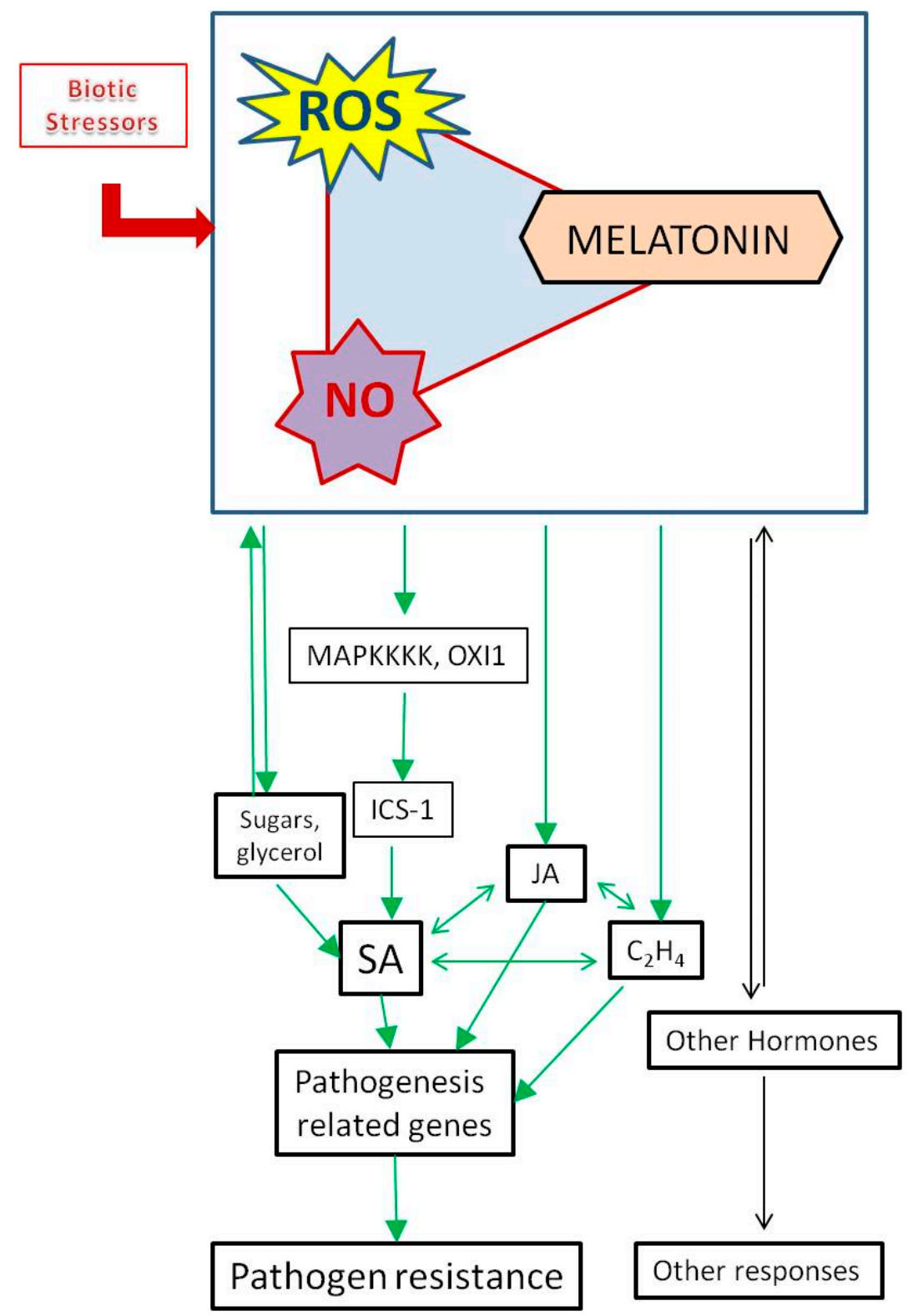

Figure 3. Model of ROS/NO/melatonin action on biotic stress responses (pathogen resistance).

\section{Future Perspectives for Melatonin and SA in Agronomic Applications}

Both molecules are of great interest as modulating agents of anti-stress responses in plants. Also, both have the capacity to directly or indirectly interact with ROS and RNS. Knowledge of the possible relationships with other hormones in aspects related to pathogen resistance and the response to abiotic stresses is of great relevance. The possibility of "sensitizing" plants to abiotic agents through priming or other methods might be of interest in order to increase the resistance of crops. SA- or melatonin-induced activation to reduce damage caused by water deficits (drought), while maintaining 
the proper metabolism in the face of this stress situation is clearly an essential objective for increasing plant/crop development and yield. Obtaining transgenic plants that overexpressed SA and melatonin biosynthesis genes could be another interesting approach, both for research per se and for application in crops, provided that the limitations to the use of transgenic plants are not transgressed. In both cases, the over-accumulation of SA and melatonin in plant tissues increase the resistance response against stressors. Figure 4 shows a schematic model in which both molecules studied in this paper present agonist behaviour to reduce or moderate the harm caused by stressors with the final aim of improving plant development and crop yield.

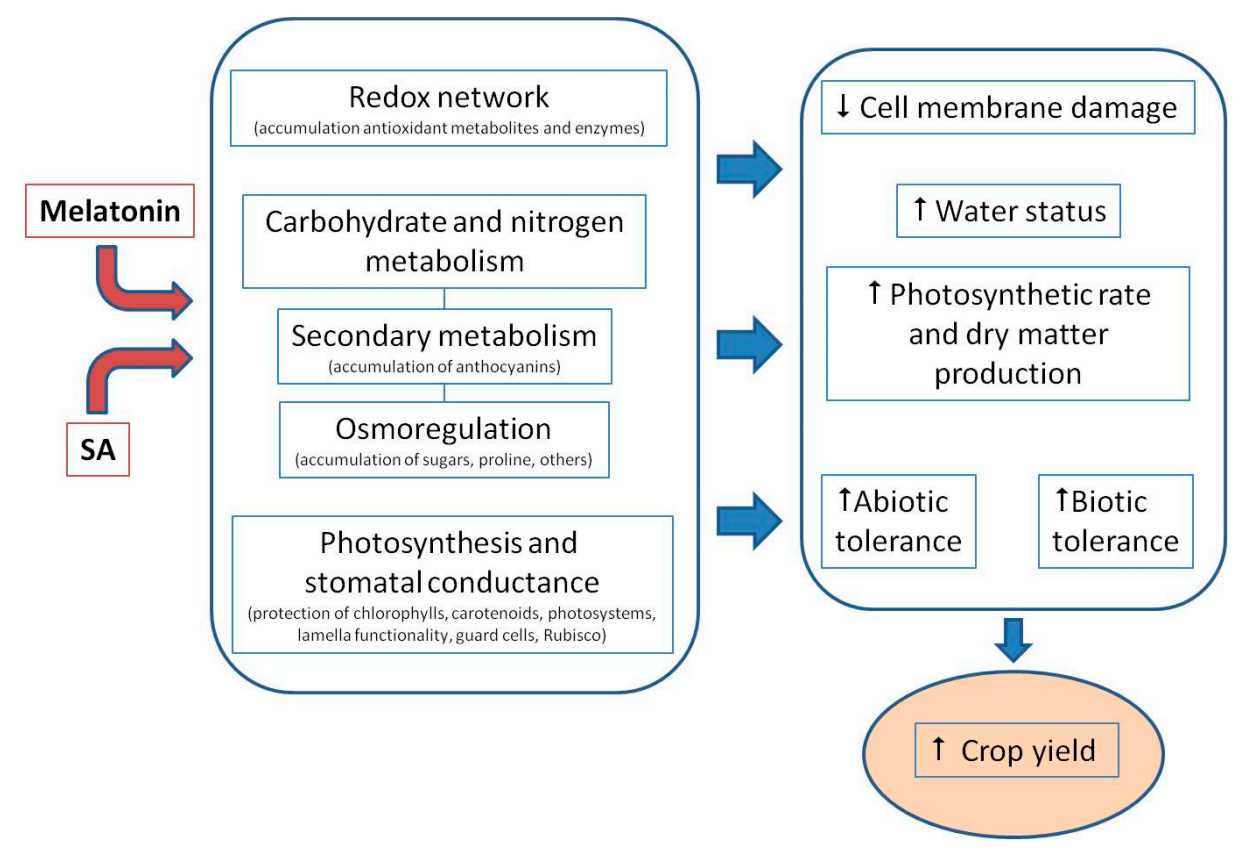

Figure 4. Melatonin/SA model of biostimulating activity in plants to enhance resistance to stress situations and increase crop yield.

Acknowledgments: Thanks to P. Díaz Vivancos for his generous invitation.

Author Contributions: Marino B. Arnao conceived and designed work. Marino B. Arnao and Josefa Hernández-Ruiz analyzed the data. Marino B. Arnao wrote the manuscript. Marino B. Arnao and Josefa Hernández-Ruiz critically revised the final version of manuscript. Marino B. Arnao and Josefa Hernández-Ruiz read and approved the final article.

Conflicts of Interest: The authors declare no conflict of interest.

\section{References}

1. Lerner, A.B.; Case, J.D.; Takahashi, Y.; Lee, T.H.; Mori, W. Isolation of melatonin, a pineal factor that lightens melanocytes. J. Am. Chem. Soc. 1958, 80, 2587. [CrossRef]

2. Lerner, A.; Case, J.; Mori, W.; Wright, M. Melatonin in peripheral nerve. Nature 1959, 183, 1821. [CrossRef] [PubMed]

3. Hattori, A.; Migitaka, H.; Iigo, M.; Yamamoto, K.; Ohtani-Kaneko, R.; Hara, M.; Suzuki, T.; Reiter, R.J. Identification of melatonin in plants and its effects on plasma melatonin levels and binding to melatonin receptors in vertebrates. Biochem. Mol. Biol. Int. 1995, 35, 627-634. [PubMed]

4. Dubbels, R.; Reiter, R.J.; Klenke, E.; Goebel, A.; Schnakenberg, E.; Ehlers, C.; Schiwara, H.W.; Schloot, W. Melatonin in edible plants identified by radioimmunoassay and by HPLC-MS. J. Pineal Res. 1995, 18, $28-31$. [CrossRef] [PubMed] 
5. Blask, D.E.; Dauchy, R.T.; Sauer, L.A.; Krause, J.A. Melatonin uptake and growth prevention in rat hepatoma 7288CTC in response to dietary melatonin: Melatonin receptor-mediated inhibition of tumor linoleic acid metabolism to the growth signaling molecule 13-hydroxyoctadecadienoic acid and the potential role of phytomelatonin. Carcinogenesis 2004, 25, 951-960. [PubMed]

6. Arnao, M.B.; Hernández-Ruiz, J. The potential of phytomelatonin as a nutraceutical. Molecules 2018, 23, 238. [CrossRef] [PubMed]

7. Back, K.; Tan, D.X.; Reiter, R.J. Melatonin biosynthesis in plants: Multiple pathways catalyze tryptophan to melatonin in the cytoplasm or chloroplasts. J. Pineal Res. 2016, 61, 426-437. [CrossRef] [PubMed]

8. Shamsul, H.; Aqil, A.; Alyemeni, M.N. (Eds.) Salicylic Acid: Plant. Growth and Development; Springer: London, UK, 2013; ISBN 978-94-007-6427-9.

9. Vlot, A.C.; Dempsey, D.A.; Klessig, D.F. Salicylic acid, a multi-faceted hormone to combat disease. Annu. Rev. Phytopathol. 2009, 47, 177-206. [CrossRef] [PubMed]

10. Mustafa, N.R.; Kim, H.K.; Choi, Y.H.; Erkelens, C.; Lefeber, A.W.M.; Spijksma, G.; Heijden, R.V.D.; Verpoorte, R. Biosynthesis of salicylic acid in fungus elicited Catharanthus roseus cells. Phytochemistry 2009, 70, 532-539. [CrossRef] [PubMed]

11. Horváth, E.; Pál, M.; Szalai, G.; Páldi, E.; Janda, T. Exogenous 4-hydroxybenzoic acid and salicylic acid modulate the effect of short-term drought and freezing stress on wheat plants. Biol. Plant. 2007, 51, 480-487. [CrossRef]

12. An, C.; Mou, Z. Salicylic acid and its function in plant immunity. J. Integr. Plant Biol. 2011, 53, 412-428. [CrossRef] [PubMed]

13. Byeon, Y.; Tan, D.X.; Reiter, R.J.; Back, K. Predominance of 2-hydroxymelatonin over melatonin in plants. J. Pineal Res. 2015, 59, 448-454. [CrossRef] [PubMed]

14. Hernández-Ruiz, J.; Cano, A.; Arnao, M.B. Melatonin: Growth-stimulating compound present in lupin tissues. Planta 2004, 220, 140-144. [CrossRef] [PubMed]

15. Arnao, M.B.; Hernández-Ruiz, J. Melatonin promotes adventitious- and lateral root regeneration in etiolated hypocotyls of Lupinus albus L. J. Pineal Res. 2007, 42, 147-152. [CrossRef] [PubMed]

16. Lei, X.Y.; Zhu, R.Y.; Zhang, G.Y.; Dai, Y.R. Attenuation of cold-induced apoptosis by exogenous melatonin in carrot suspension cells: The possible involvement of polyamines. J. Pineal Res. 2004, 36, 126-131. [CrossRef] [PubMed]

17. Arnao, M.B.; Hernández-Ruiz, J. Functions of melatonin in plants: A review. J. Pineal Res. 2015, 59, $133-150$. [CrossRef] [PubMed]

18. Arnao, M.B.; Hernández-Ruiz, J. Melatonin: Plant growth regulator and/or biostimulator during stress? Trends Plant Sci. 2014, 19, 789-797. [CrossRef] [PubMed]

19. Carswell, G.K.; Johnson, C.M.; Shillito, R.D.; Harms, C.T. O-acetyl-salicylic acid promotes colony formation from protoplasts of an elite maize inbred. Plant Cell Rep. 1989, 8, 282-284. [CrossRef] [PubMed]

20. Eberhard, S.; Doubrava, N.; Marfa, V.; Mohnen, D.; Southwick, A.; Darvill, A.; Albersheim, P. Pectic cell wall fragments regulate tobacco thin-cell-layer explant morphogenesis. Plant Cell 1989, 1, 747. [CrossRef] [PubMed]

21. Malamy, J.; Carr, J.P.; Klessig, D.F.; Raskin, I. Salicylic acid: A likely endogenous signal in the resistance response of tobacco to viral infection. Science 1990, 250, 100-1004. [CrossRef] [PubMed]

22. Métraux, J.P.; Signer, H.; Ryals, J.; Ward, E.; Wyss-Benz, M.; Gaudin, J.; Raschdorf, K.; Schmid, E.; Blum, W.; Inverardi, B. Increase in salicylic acid at the onset of systemic acquired resistance in cucumber. Science 1990, 250, 1004-1006. [CrossRef] [PubMed]

23. Pál, M.; Kovács, V.; Szalai, G.; Soós, V.; Ma, X.; Liu, H.; Mei, H.; Janda, T. Salicylic acid and abiotic stress responses in rice. J. Agron. Crop Sci. 2014, 200, 1-11. [CrossRef]

24. Raskin, I.; Ehmann, A.; Melander, W.R.; Bastiaan, J.D.M. Salicylic acid: A natural inducer of heat production in Arum lilies. Science 1987, 237, 1601-1602. [CrossRef] [PubMed]

25. Arnao, M.B.; Hernández-Ruiz, J. Melatonin in its relationship to plant hormones. Ann. Bot. 2018, 211, 195-207. [CrossRef] [PubMed]

26. Verma, V.; Ravindran, P.; Kumar, P.P. Plant hormone-mediated regulation of stress responses. BMC Plant Biol. 2016, 16, 86. [CrossRef] [PubMed]

27. Khan, M.I.; Fatma, M.; Per, T.S.; Anjum, N.A.; Khan, N.A. Salicylic acid-induced abiotic stress tolerance and underlying mechanisms in plants. Front. Plant Sci. 2015, 6, 462. [CrossRef] [PubMed] 
28. Pál, M.; Szalai, G.; Kovács, V.; Gondor, O.K.; Janda, T. Salicylic acid-mediated abiotic stress tolerance. In Salicylic Acid: Plant Growth and Development; Shamsul, H., Aqil, A., Alyemeni, M.N., Eds.; Springer: London, UK, 2013; pp. 183-247. ISBN 978-94-007-6427-9.

29. Arnao Marino, B.; Hernández-Ruiz, J. Melatonin: Synthesis from tryptophan and its role in higher plants. In Amino Acids in Higher Plants; D'Mello, J.P.F., Ed.; CAB International: Boston, MA, USA, 2015; pp. 390-435. ISBN 978-1-78064-263-5.

30. Wang, Y.; Reiter, R.J.; Chan, Z. Phytomelatonin: A universal abiotic stress regulator. J. Exp. Bot. 2018, 69, 963-974. [CrossRef] [PubMed]

31. Bajwa, V.S.; Shukla, M.R.; Sherif, S.M.; Murch, S.J.; Saxena, P.K. Role of melatonin in alleviating cold stress in Arabidopsis thaliana. J. Pineal Res. 2014, 56, 238-245. [CrossRef] [PubMed]

32. Shi, H.; Chan, Z. The Cysteine2/Histidine2-type transcription factor ZINC FINGER OF ARABIDOPSIS THALIANA 6-activated C-REPEAT-BINDING FACTOR pathway is essential for melatonin-mediated freezing stress resistance in Arabidopsis. J. Pineal Res. 2014, 57, 185-191. [CrossRef] [PubMed]

33. Balabusta, M.; Szafranska, K.; Posmyk, M.M. Exogenous melatonin improves antioxidant defense in cucumber seeds germinated under chilling stress. Front. Plant Sci. 2016, 7, 575. [CrossRef]

34. Zhao, Y.; Qi, L.W.; Wang, W.M.; Saxena, P.K.; Liu, C.Z. Melatonin improves the survival of cryopreserved callus of Rhodiola crenulata. J. Pineal Res. 2011, 50, 83-88. [CrossRef] [PubMed]

35. Uchendu, E.E.; Shukla, M.R.; Reed, B.M.; Saxena, P.K. Melatonin enhances the recovery of cryopreserved shoot tips of American elm (Ulmus americana L.). J. Pineal Res. 2013, 55, 435-442. [PubMed]

36. Li, H.; Dong, Y.; Chang, J.; He, J.; Chen, H.; Liu, Q.; Wei, C.; Ma, J.; Zhang, Y.; Yang, J.; et al. High-throughput microRNA and mRNA sequencing reveals that microRNAs may be involved in melatonin-mediated cold tolerance in Citrullus lanatus L. Front. Plant Sci. 2016, 7, 1231. [CrossRef] [PubMed]

37. Turk, H.; Erdal, S.; Genisel, M.; Atici, O.; Demir, Y.; Yanmis, D. The regulatory effect of melatonin on physiological, biochemical and molecular parameters in cold-stressed wheat seedlings. Plant Growth Regul. 2014, 74, 139-152. [CrossRef]

38. Zhang, N.; Sun, Q.; Li, H.; Cao, Y.; Zhang, H.; Li, S.; Zhang, L.; Qi, Y.; Ren, S.; Zhao, B.; et al. Melatonin improved anthocyanin accumulation by regulating gene expressions and resulted in high reactive oxygen species scavenging capacity in cabbage. Front. Plant Sci. 2016, 7, 197. [CrossRef] [PubMed]

39. Shi, H.; Jiang, C.; Ye, T.; Tan, D.; Reiter, R.J.; Zhang, H.; Liu, R.; Chan, Z. Comparative physiological, metabolomic, and transcriptomic analyses reveal mechanisms of improved abiotic stress resistance in bermudagrass [Cynodon dactylon (L). Pers.] by exogenous melatonin. J. Exp. Bot. 2015, 66, 681-694. [CrossRef] [PubMed]

40. Fan, J.; Hu, Z.; Xie, Y.; Chan, Z.; Chen, K.; Amombo, E.; Chen, L.; Fu, J. Alleviation of cold damage to photosystem II and metabolisms by melatonin in Bermudagrass. Front. Plant Sci. 2015, 6, 925. [CrossRef] [PubMed]

41. Shi, H.; Qian, Y.; Tan, D.X.; Reiter, R.J.; He, C. Melatonin induces the transcripts of CBF/DREB1s and their involvement in both abiotic and biotic stresses in Arabidopsis. J. Pineal Res. 2015, 59, 334-342. [CrossRef] [PubMed]

42. Li, X.; Tan, D.X.; Jiang, D.; Liu, F. Melatonin enhances cold tolerance in drought-primed wild-type and abscisic acid-deficient mutant barley. J. Pineal Res. 2016, 61, 328-339. [CrossRef] [PubMed]

43. Tiryaki, I.; Keles, H. Reversal of the inhibitory effect of light and high temperature on germination of Phacelia tanacetifolia seeds by melatonin. J. Pineal Res. 2012, 52, 332-339. [CrossRef] [PubMed]

44. Shi, H.; Tan, D.X.; Reiter, R.J.; Ye, T.; Yang, F.; Chan, Z. Melatonin induces class A1 heat shock factors (HSFA1s) and their possible involvement of thermotolerance in Arabidopsis. J. Pineal Res. 2015, 58, 335-342. [CrossRef] [PubMed]

45. Xu, W.; Cai, S.Y.; Zhang, Y.; Wang, Y.; Ahammed, G.J.; Xia, X.J.; Shi, K.; Zhou, Y.H.; Yu, J.Q.; Reiter, R.J.; et al. Melatonin enhances thermotolerance by promoting cellular protein protection in tomato plants. J. Pineal Res. 2016, 61, 457-469. [CrossRef] [PubMed]

46. Tan, D.X.; Manchester, L.C.; Helton, P.; Reiter, R.J. Phytoremediative capacity of plants enriched with melatonin. Plant Signal. Behav. 2007, 2, 514-516. [CrossRef] [PubMed]

47. Posmyk, M.M.; Kuran, H.; Marciniak, K.; Janas, K.M. Presowing seed treatment with melatonin protects red cabbage seedlings against toxic copper ion concentrations. J. Pineal Res. 2008, 45, 24-31. [CrossRef] [PubMed] 
48. Hasan, M.; Ahammed, G.J.; Yin, L.; Shi, K.; Xia, X.; Zhou, Y.; Yu, J.; Zhou, J. Melatonin mitigates cadmium phytotoxicity through modulation of phytochelatins biosynthesis, vacuolar sequestration and antioxidant potential in Solanum lycopersicum L. Front. Plant Sci. 2015, 6, 601. [CrossRef] [PubMed]

49. Kobylinska, A.; Posmyk, M.M. Melatonin restricts Pb-induced PCD by enhancing BI-1 expression in tobacco suspension cells. Biometals 2016, 29, 1059-1074. [CrossRef] [PubMed]

50. Wang, P.; Sun, X.; Wang, N.; Tan, D.X.; Ma, F. Melatonin enhances the occurrence of autophagy induced by oxidative stress in Arabidopsis seedlings. J. Pineal Res. 2015, 58, 479-489. [CrossRef] [PubMed]

51. Szafranska, K.; Reiter, R.J.; Posmyk, M.M. Melatonin application to Pisum sativum L. seeds positively influences the function of the photosynthetic apparatus in growing seedlings during paraquat-induced oxidative stress. Front. Plant Sci. 2016, 7, 1663. [CrossRef] [PubMed]

52. Li, C.; Wang, P.; Wei, Z.; Liang, D.; Jia, D.; Fu, M.; Ma, F. The mitigation effects of exogenous melatonin on salinity-induced stress in Malus hupehensis. J. Pineal Res. 2012, 53, 298-306. [CrossRef] [PubMed]

53. Li, C.; Liang, B.; Chang, C.; Wei, Z.; Zhou, S.; Ma, F. Exogenous melatonin improved potassium content in Malus under different stress conditions. J. Pineal Res. 2016, 61, 218-229. [CrossRef] [PubMed]

54. Kostopoulou, Z.; Therios, I.; Roumeliotis, E.; Kanellis, A.K.; Molassiotis, A. Melatonin combined with ascorbic acid provides salt adaptation in Citrus aurantium L. seedlings. Plant Physiol. Biochem. 2015, 86, 155-165. [CrossRef] [PubMed]

55. Mukherjee, S.; David, A.; Yadav, S.; Baluska, F.; Bhatla, S.C. Salt stress-induced seedling growth inhibition coincides with differential distribution of serotonin and melatonin in sunflower seedling roots and cotyledons. Physiol. Plant. 2014, 152, 714-728. [CrossRef] [PubMed]

56. Zhang, H.J.; Zhang, N.; Yang, R.C.; Wang, L.; Sun, Q.Q.; Li, D.B.; Cao, Y.Y.; Weeda, S.; Zhao, B.; Ren, S.; et al. Melatonin promotes seed germination under high salinity by regulating antioxidant systems, ABA and GA4 interaction in cucumber (Cucumis sativus L.). J. Pineal Res. 2014, 57, 269-279. [CrossRef] [PubMed]

57. Dawood, M.G.; El-Awadi, M.E. Alleviation of salinity stress on Vicia faba L. plants via seed priming with melatonin. Acta Biol. Colomb. 2015, 20, 223-235. [CrossRef]

58. Zhou, X.; Zhao, H.; Cao, K.; Hu, L.; Du, T.; Baluska, F.; Zou, Z. Beneficial roles of melatonin on redox regulation of photosynthetic electron transport and synthesis of $\mathrm{D} 1$ protein in tomato seedlings under salt stress. Front. Plant Sci. 2016, 7, 1823. [CrossRef] [PubMed]

59. Liu, N.; Jin, Z.; Wang, S.; Gong, B.; Wen, D.; Wang, X.; Wei, M.; Shi, Q. Sodic alkaline stress mitigation with exogenous melatonin involves reactive oxygen metabolism and ion homeostasis in tomato. Sci. Hortic. 2015, 181, 18-25. [CrossRef]

60. Wei, W.; Li, Q.; Chu, Y.-N.; Reiter, R.J.; Yu, X.M.; Zhu, D.H.; Zhang, W.K.; Ma, B.; Lin, Q.; Zhang, J.S.; et al. Melatonin enhances plant growth and abiotic stress tolerance in soybean plants. J. Exp. Bot. 2015, 66, 695-707. [CrossRef] [PubMed]

61. Zhang, N.; Zhao, B.; Zhang, H.J.; Weeda, S.; Yang, C.; Yang, Z.C.; Ren, S.; Guo, Y.D. Melatonin promotes water-stress tolerance, lateral root formation, and seed germination in cucumber (Cucumis sativus L.). J. Pineal Res. 2013, 54, 15-23. [CrossRef] [PubMed]

62. Meng, J.F.; Xu, T.F.; Wang, Z.Z.; Fang, Y.L.; Xi, Z.M.; Zhang, Z.W. The ameliorative effects of exogenous melatonin on grape cuttings under water-deficient stress: Antioxidant metabolites, leaf anatomy, and chloroplast morphology. J. Pineal Res. 2014, 57, 200-212. [CrossRef] [PubMed]

63. Li, C.; Liang, D.; Chang, C.; Jia, D.; Ma, F. Melatonin mediates the regulation of ABA metabolism, free-radical scavenging, and stomatal behavior in two Malus species under drought stress. J. Exp. Bot. 2015, 66, 669-680. [CrossRef] [PubMed]

64. Arnao, M.B.; Hernández-Ruiz, J. Protective effect of melatonin against chlorophyll degradation during the senescence of barley leaves. J. Pineal Res. 2009, 46, 58-63. [CrossRef] [PubMed]

65. Wang, P.; Yin, L.; Liang, D.; Li, C.; Ma, F.; Yue, Z. Delayed senescence of apple leaves by exogenous melatonin treatment: Toward regulating the ascorbate-glutathione cycle. J. Pineal Res. 2012, 53, 11-20. [CrossRef] [PubMed]

66. Wang, P.; Sun, X.; Li, C.; Wei, Z.; Liang, D.; Ma, F. Long-term exogenous application of melatonin delays drought-induced leaf senescence in apple. J. Pineal Res. 2013, 54, 292-302. [CrossRef] [PubMed]

67. Shi, H.; Reiter, R.J.; Tan, D.X.; Chan, Z. INDOLE-3-ACETIC ACID INDUCIBLE 17 positively modulates natural leaf senescence through melatonin-mediated pathway in Arabidopsis. J. Pineal Res. 2015, 58, $26-33$. [CrossRef] [PubMed] 
68. Liang, C.; Zheng, G.; Li, W.; Wang, Y.; Hu, B.; Wang, H.; Wu, H.; Qian, Y.; Zhu, X.G.; Tan, D.X.; et al. Melatonin delays leaf senescence and enhances salt stress tolerance in rice. J. Pineal Res. 2015, 59, 91-101. [CrossRef] [PubMed]

69. Zhang, J.; Li, H.; Xu, B.; Li, J.; Huang, B. Exogenous melatonin suppresses dark-induced leaf senescence by activating the superoxide dismutase-catalase antioxidant pathway and down-regulating chlorophyll degradation in excised leaves of perennial ryegrass (Lolium perenne L.). Front. Plant Sci. 2016, 7, 1500. [CrossRef] [PubMed]

70. Mutlu, S.; Karadagoglu, O.; Atici, O.; Nalbantoglu, B. Protective role of salicylic acid applied before cold stress on antioxidative system and protein patterns in barley apoplast. Biol. Plant. 2013, 57, 507-513. [CrossRef]

71. Kang, G.Z.; Wang, Z.X.; Xia, K.F.; Sun, G.C. Protection of ultrastructure in chilling-stressed banana leaves by salicylic acid. J. Zhejiang Univ. Sci. B 2007, 8, 277-282. [CrossRef] [PubMed]

72. Ding, C.K.; Wang, C.; Gross, K.C.; Smith, D.L. Jasmonate and salicylate induce the expression of pathogenesis-related-protein genes and increase resistance to chilling injury in tomato fruit. Planta 2002, 214, 895-901. [CrossRef] [PubMed]

73. Wang, L.; Chen, S.; Kong, W.; Li, S.; Archbold, D.D. Salicylic acid pretreatment alleviates chilling injury and affects the antioxidant system and heat shock proteins of peaches during cold storage. Postharvest Biol. Technol. 2006, 41, 244-251. [CrossRef]

74. Khan, M.I.; Iqbal, N.; Masood, A.; Per, T.S.; Khan, N.A. Salicylic acid alleviates adverse effects of heat stress on photosynthesis through changes in proline production and ethylene formation. Plant Signal. Behav. 2013, 8, e26374. [CrossRef] [PubMed]

75. Larkindale, J.; Knight, M.R. Protection against heat stress-induced oxidative damage in Arabidopsis involves calcium, abscisic acid, ethylene, and salicylic acid. Plant Physiol. 2002, 128, 682-695. [CrossRef] [PubMed]

76. Ahmad, P.; Nabi, G.; Ashraf, M. Cadmium-induced oxidative damage in mustard [Brassica juncea (L.) Czern. \& Coss.] plants can be alleviated by salicylic acid. S. Afr. J. Bot. 2011, 77, 36-44.

77. Zhang, Y.; Xu, S.; Yang, S.; Chen, Y. Salicylic acid alleviates cadmium-induced inhibition of growth and photosynthesis through upregulating antioxidant defense system in two melon cultivars (Cucumis melo L.). Protoplasma 2015, 252, 911-924. [CrossRef] [PubMed]

78. Noriega, G.; Caggiano, E.; Lecube, M.L.; Cruz, D.S.; Batlle, A.; Tomaro, M.; Balestrasse, K.B. The role of salicylic acid in the prevention of oxidative stress elicited by cadmium in soybean plants. Biometals 2012, 25, 1155-1165. [CrossRef] [PubMed]

79. Liu, C.; Guo, J.; Cui, Y.; Láo, T.; Zhang, X.; Shi, G. Effects of cadmium and salicylic acid on growth, spectral reflectance and photosynthesis of castor bean seedlings. Plant Soil 2011, 344, 131-141. [CrossRef]

80. Ardebili, N.O.; Saadatmand, S.; Niknam, V.; Khavari-Nejad, R.A. The alleviating effects of selenium and salicylic acid in salinity exposed soybean. Acta Physiol. Plant. 2014, 36, 3199-3205. [CrossRef]

81. Khan, M.I.; Asgher, M.; Khan, N.A. Alleviation of salt-induced photosynthesis and growth inhibition by salicylic acid involves glycinebetaine and ethylene in mungbean (Vigna radiata L.). Plant Physiol. Biochem. 2014, 80, 67-74. [CrossRef] [PubMed]

82. Li, T.; Hu, Y.; Du, X.; Tang, H.; Shen, C.; Wu, J. Salicylic acid alleviates the adverse effects of salt stress in Torreya grandis cv. Merrillii seedlings by activating photosynthesis and enhancing antioxidant systems. PLoS ONE 2014, 9, e109492. [CrossRef] [PubMed]

83. Saruhan, N.; Saglam, A.; Kadioglu, A. Salicylic acid pretreatment induces drought tolerance and delays leaf rolling by inducing antioxidant systems in maize genotypes. Acta Physiol. Plant. 2012, 34, 97-106. [CrossRef]

84. Awate, P.D.; Gaikwad, D.K. Influence of growth regulators on secondary metabolites of medicinally important oil yielding plant Simarouba glauca DC. under water stress conditions. J. Stress Physiol. Biochem. 2014, 10, 222-229.

85. Singh, B.; Usha, K. Salicylic acid induced physiological and biochemical changes in wheat seedlings under water stress. Plant Growth Regul. 2003, 39, 137-141. [CrossRef]

86. Ervin, E.H.; Zhang, X.Z.; Fike, J.H. Ultraviolet-B radiation damage on Kentucky Bluegrass II: Hormone supplement effects. Hortic. Sci. 2004, 39, 1471-1474.

87. Yin, L.; Wang, P.; Li, M.; Ke, X.; Li, C.; Liang, D.; Wu, S.; Ma, X.; Li, C.; Zou, Y.; et al. Exogenous melatonin improves Malus resistance to Marssonina apple blotch. J. Pineal Res. 2013, 54, 426-434. [CrossRef] [PubMed] 
88. Zhang, S.; Zheng, X.; Reiter, R.J.; Feng, S.; Wang, Y.; Liu, S.; Jin, L.; Li, Z.; Datla, R.; Ren, M. Melatonin attenuates potato late blight by disrupting cell growth, stress tolerance, fungicide susceptibility and homeostasis of gene expression in Phytophthora infestans. Front. Plant Sci. 2017, 8, 1993. [CrossRef] [PubMed]

89. Lee, H.Y.; Byeon, Y.; Tan, D.X.; Reiter, R.J.; Back, K. Arabidopsis serotonin N-acetyltransferase knockout mutant plants exhibit decreased melatonin and salicylic acid levels resulting in susceptibility to an avirulent pathogen. J. Pineal Res. 2015, 58, 291-299. [CrossRef] [PubMed]

90. Vielma, J.R.; Bonilla, E.; Chacín-Bonilla, L.; Mora, M.; Medina-Leendertz, S.; Bravo, Y. Effects of melatonin on oxidative stress, and resistance to bacterial, parasitic, and viral infections: A review. Acta Trop. 2014, 137, 31-38. [CrossRef] [PubMed]

91. Lee, H.Y.; Byeon, Y.; Back, K. Melatonin as a signal molecule triggering defense responses against pathogen attack in Arabidopsis and tobacco. J. Pineal Res. 2014, 57, 262-268. [CrossRef] [PubMed]

92. Shi, H.; Chen, Y.; Tan, D.X.; Reiter, R.J.; Chan, Z.; He, C. Melatonin induces nitric oxide and the potential mechanisms relate to innate immunity against bacterial pathogen infection in Arabidopsis. J. Pineal Res. 2015, 59, 102-108. [CrossRef] [PubMed]

93. Lee, H.Y.; Back, K. Mitogen-activated protein kinase pathways are required for melatonin-mediated defense responses in plants. J. Pineal Res. 2016, 60, 327-335. [CrossRef] [PubMed]

94. Shi, H.; Wei, Y.; He, C. Melatonin-induced CBF/DREB1s are essential for diurnal change of disease resistance and CCA1 expression in Arabidopsis. Plant. Physiol. Biochem. 2016, 100, 150-155. [CrossRef] [PubMed]

95. Wei, Y.; Zeng, H.; Hu, W.; Chen, L.; He, C.; Shi, H. Comparative transcriptional profiling of melatonin synthesis and catabolic genes indicates the possible role of melatonin in developmental and stress responses in rice. Front. Plant Sci. 2016, 7, 676. [CrossRef] [PubMed]

96. Wei, Y.; Chang, Y.; Zeng, H.; Liu, G.; He, C.; Shi, H. RAV transcription factors are essential for disease resistance against cassava bacterial blight via activation of melatonin biosynthesis genes. J. Pineal Res. 2018, 64, e12454. [CrossRef] [PubMed]

97. Wang, Y.Y.; Li, B.Q.; Qin, G.Z.; Li, L.; Tian, S.P. Defense response of tomato fruit at different maturity stages to salicylic acid and ethephon. Sci. Hortic. 2011, 129, 183-188. [CrossRef]

98. Chivasa, S.; Murphy, A.M.; Naylor, M.; Carr, J.P. Salicylic acid interferes with tobacco mosaic virus replication via a novel salicylhydroxamic acid-sensitive mechanism. Plant Cell 1997, 9, 547-557. [CrossRef] [PubMed]

99. Murphy, A.M.; Carr, J.P. Salicylic acid has cell-specific effects on tobacco mosaic virus replication and cell-to-cell movement. Plant Physiol. 2002, 128, 552-563. [CrossRef] [PubMed]

100. Tian, M.; Sasvari, Z.; Gonzalez, P.A.; Friso, G.; Rowland, E.; Liu, X.M.; van Wijk, K.J.; Nagy, P.D.; Klessig, D.F. Salicylic acid inhibits the replication of tomato bushy stunt virus by directly targeting a host component in the replication complex. Mol. Plant Microbe Interact. 2015, 28, 379-386. [CrossRef] [PubMed]

101. Babalar, M.; Asghari, M.; Talaei, A.; Khosroshahi, A. Effect of pre- and postharvest salicylic acid treatment on ethylene production, fungal decay and overall quality of Selva strawberry fruit. Food Chem. 2007, 105, 449-453. [CrossRef]

102. Joyce, D.C.; Wearing, H.; Coates, L.; Terry, L. Effects of phosphonate and salicylic acid treatments on anthracnose disease development and ripening of 'Kensington Pride' mango fruit. Aust. J. Exp. Agric. 2001, 41, 805-813.

103. Yu, T.; Zheng, X.D. Salicylic acid enhances biocontrol efficacy of the antagonist Cryptococcus laurentii in apple fruit. J. Plant Growth Regul. 2006, 25, 166-174. [CrossRef]

104. Xu, X.; Tian, S. Salicylic acid alleviated pathogen-induced oxidative stress in harvested sweet cherry fruit. Postharvest Biol. Technol. 2008, 49, 379-385. [CrossRef]

105. Cao, J.; Zeng, K.; Jiang, W. Enhancement of postharvest disease resistance in Ya Li pear (Pyrus bretschneideri) fruit by salicylic acid sprays on the trees during fruit growth. Eur. J. Plant Pathol. 2006, 114, 363-370. [CrossRef]

106. Astier, J.; Loake, G.; Velikova, V.; Gaupels, F. Editorial: Interplay between NO signaling, ROS, and the antioxidant system in plants. Front. Plant Sci. 2016, 7, 1731. [CrossRef] [PubMed]

107. León, J.; Costa, A.; Castillo, M.C. Nitric oxide triggers a transient metabolic reprogramming in Arabidopsis. Sci. Rep. 2016, 6, 37945. [CrossRef] [PubMed]

108. Pucciariello, C.; Perata, P. New insights into reactive oxygen species and nitric oxide signalling under low oxygen in plants. Plant Cell Environ. 2017, 40, 473-482. [CrossRef] [PubMed] 
109. Del Rio, L.A.; López-Huertas, E. ROS generation in peroxisomes and its role in cell signaling. Plant Cell Environ. 2016, 57, 1364-1376. [CrossRef] [PubMed]

110. Saxena, I.; Srikanth, S.; Chen, Z. Cross talk between $\mathrm{H}_{2} \mathrm{O}_{2}$ and interacting signal molecules under plant stress response. Front. Plant Sci. 2016, 7, 570. [CrossRef] [PubMed]

111. Damiani, I.; Pauly, N.; Puppo, A.; Brouquisse, R.; Boscari, A. Reactive oxygen species and nitric oxide control early steps of the legume-Rhizobium symbiotic interaction. Front. Plant Sci. 2016, 7, 454. [CrossRef] [PubMed]

112. Molassiotis, A.; Job, D.; Ziogas, V.; Tanou, G. Citrus Plants: A model system for unlocking the secrets of NO and ROS-inspired priming against salinity and drought. Front. Plant Sci. 2016, 7, 229. [CrossRef] [PubMed]

113. Wen, D.; Gong, B.; Sun, S.; Liu, S.; Wang, X.; Wei, M.; Yang, F.; Li, Y.; Shi, Q. Promoting roles of melatonin in adventitious root development of Solanum lycopersicum L. by regulating auxin and nitric oxide signaling. Front. Plant Sci. 2016, 7, 718. [CrossRef] [PubMed]

114. Sun, H.; Feng, F.; Liu, J.; Zhao, Q. The Interaction between auxin and nitric oxide regulates root growth in response to iron deficiency in rice. Front. Plant Sci. 2017, 8, 2169. [CrossRef] [PubMed]

115. Fleta-Soriano, E.; Díaz, L.; Bonet, E.; Munné-Bosch, S. Melatonin may exert a protective role against drought stress in maize. J. Agron. Crop Sci. 2017, 203, 286-294. [CrossRef]

116. Lee, H.Y.; Back, K. Melatonin is required for $\mathrm{H}_{2} \mathrm{O}_{2}$ - and NO-mediated defense signaling through MAPKKK3 and OXI1 in Arabidopsis thaliana. J. Pineal Res. 2017, 62, e12379. [CrossRef] [PubMed]

117. Shyu, C.; Brutnell, T.P. Growth-defence balance in grass biomass production: The role of jasmonates. J. Exp. Bot. 2015, 66, 4165-4176. [CrossRef] [PubMed]

118. Qian, Y.; Tan, D.X.; Reiter, R.J.; Shi, H. Comparative metabolomic analysis highlights the involvement of sugars and glycerol in melatonin-mediated innate immunity against bacterial pathogen in Arabidopsis. Sci. Rep. 2015, 5, 15815. [CrossRef] [PubMed]

119. Overmyer, K.; Vuorinen, K.; Brosché, M. Interaction points in plant stress signaling pathways. Physiol. Plant 2018, 162, 191-204. [CrossRef] [PubMed]

(C) 2018 by the authors. Licensee MDPI, Basel, Switzerland. This article is an open access article distributed under the terms and conditions of the Creative Commons Attribution (CC BY) license (http:/ / creativecommons.org/licenses/by/4.0/). 